\title{
He Conquered the Jungle: A Celebration of the Indefatigable Human Spirit
}

\author{
Suganthi S. Kumar and K. Akilandeeswari \\ 'Associate Professor, Department of English, PSG College of Technology, Coimbatore - 641004, \\ Tamil Nadu, India; sugan_eskay@yahoo.co.in \\ ${ }^{2}$ Associate Professor, Department of English, Ministry of Higher Education, King Khalid University, \\ Mohail, Assir, Kingdom Of Saudi Arabia; drakila_cbe1@yahoo.co.in
}

\begin{abstract}
This paper celebrates the indefatigable human spirit of the protagonist in Kesava Reddy's novel He Conquered the Jungle. In every part of the story, his courage, determination and endurance for survival is expressed. He sets the best example to the younger generation who lacks in these qualities. The story spins around just for a night, but the experience of the protagonist from dusk to dawn is compared with the lifespan of humankind from birth to death. One will certainly admire this 70 year old protagonist who bravely faces all his hardships when he tries to save his sow and the piglets in the jungle. Though he suffers the greatest misfortunes and endures countless blows of ill luck, he says that is not the last day of his life. When he feels he is defeated, he stands up like a real hero and says he has other responsibilities to do, so he has to live. This optimistic view of life should be strongly inculcated in the young minds. To be a hero, one need not bring only success. A person who can face the problems confidently is also a hero. He/she is also a conqueror. Like the old man, who has conquered the jungle, everyone will be a conqueror if he/she has the indefatigable spirit within him/her.
\end{abstract}

Keywords: Endure and Overcome, Defeat and Despair, Stoicism and Courage, Survival and Triumph, Quest and Struggle

Kesava Reddy, a Telugu writer, is born in the village of Talupulapally of Chittoor District in Andhra Pradesh. He works as a physician at the Victoria Hospital in Dichpally and also writes about the neglected members of the society. The novels which are appropriately called novellas display a thematic depth, technical virtuosity and linguistic innovation that lend his works aesthetic appeal and an enduring value. His main characters are from outcast societies, who are the most neglected and least noticed members of the society. With his great understanding and acute powers of observation, he writes about their heroic battle for survival in a very natural manner. So is the present novel $\mathrm{He}$ Conquered the Jungle.

Kesava Reddy's fourth novel He Conquered the Jungle, is a translation of a Telugu novel Athadu Adavini Jainnchadu. In Telugu, it is a widely read and appreciated novel. The 70 year old protagonist, who has an unnamed swineherd and called as old man throughout the novel, is all alone in his quest and struggle. The novel seems to underline the essential loneliness of the old man, his Sisyphean struggle, and his capacity to endure and overcome it during his desperate search for his sow, which has entered the jungle looking for a safe place to give birth. Further, it throws light and appreciates the kind of stoicism and courage seen in various contexts. The highlight of the paper is the spirit- an indefatigable spirit that he has even when he receives continuous blows.

The story begins in the evening. At the time of sunset, he understands his pregnant sow has not returned, so he goes in search of her in the nearby jungle. He stops at every cave and shrub and yells Huch! Huch! But finds no clue of the sow. However, he is determined not to get back without

\footnotetext{
${ }^{*}$ Author for correspondence
} 
his sow. As it is time for the sow to deliver, the old man anticipates some danger may engulf the sow and the piglets. His anxiety increases as time passes by. For him pigs are everything and they are his sole wealth.

He continues his journey in the bright moon light when the jungle noises gradually reduce as the creatures are falling into sleep one by one. Since he treads on boulders and sharp stones, climbs hillocks and clambers down into shallow valleys and walked a long way into jungle, he could hear rumbling in his belly. For any reason, he decides not to let down his spirit. He does not want any of his emotions or human needs to be a block, and even considers his hunger to be a hindrance. To subside his hunger, he hunts a rabbit just like a hunter. Here, the author takes us to the primitive age. He makes fire with two sharp stones. He tosses and roasts the rabbit and cuts it into lumps with his knife. He squeezes the orange, which he gets it from the nearby orange tree, on the pieces of meat and rolls them in the ashes before eating them. After subsiding his hunger, he feels like lying down but decides not to until he accomplishes his duty. He says:

It is not the right time... when shall I see my sow again? I can not rest until then... I have revived my strength after a hearty meal... I may feel hungry again after sometime... as the night advances I might feel sleepy...or something else might obstruct the fulfillment of my duty. (17) [1]

Further, he moves on. On his way he finds snakes, bats, rabbits but not his sow. He tries to get some clues. He looks for the hoof prints but ends in vain. He climbs an arecanut tree and stands on the top of a branch and rakes his eyes to locate the sow. His attempts do not go a waste. When the wind grows fierce, he hears the sound of a babbler. A babbler is a seeker which announces the jungle when something unusual happens. The old man listens attentively and confirms the sound waves floating from the north east and concludes, "That's the babbler. My sow has laid its piglets somewhere in the northeast. The bird saw it and started its racket" (22) [1].

So long he has been using his eyes and ears to find the sow but now he uses his faculty of smell too. When he gets certain odour, he understands his sow has laid the piglets in the tindra bush. He also understands that he has to be very careful at this circumstance because the sow will be ferocious and will turn into a demon and tear him into pieces if he nears her or piglets. It will not be in a position to differentiate between a friend and a foe. That is the nature of a sow. He advances the bush slowly and carefully. But unfortunately, when the wind changes its direction abruptly and when the babbler finds the old man approaching meekly raises a sudden cry in double pitch. Before the old man could realize, the sow pounces on him thinking that he has come to steal or harm her piglets. As a mother, she wants to protect her babies. The author describes as:

The sow felled him and began goring him all over with her tusks. Because his nerves were numbs with fear, he did not feel the pain. He was rolling on the ground, crushing the green grass and dry sunkrenu leaves. The sow tore the muscles on his legs, thighs and shoulders with her sharp tusks. She was trying to crush his bones in the grip of her strong jaws. The beast fought with all its strength in a determination bid to pulverize the rolling, leaping man, struggling on the ground. (25) [1]

After a great struggle, he escapes from the sow by climbing up the sunkrenu tree. He sits on a branch and wonders about his escape because the sow still circles the tree and is roaring terribly with its head held up. Even though the protagonist is attacked vulnerably, his love and concern for the animal has not decreased. Rather he says, "Oai-Sukkilam... Go and lie down beside your piglets. Don't tire yourself by running around the tree" (25) [1].

Later, he realizes that his whole body is shaking due to the heavy loss of blood during the sow's attack. Even when he notices the lacerated flesh hanging from his legs and thighs and blood trickling from the wound, he has no anger on the sow. Instead his love for it only grows. He says, "But I haven't showered such love on any other either. I rolled and writhed in pain on the ground when the sow struck me but could use neither the knife I carried nor the spear in my hand" (27) [1].

He further says:

Though I've lost a lot of blood I'm not in shock. Anyone else in my place would have succumbed by now. When I saw my sow I felt as if I were riding an elephant. Even if all the soldiers of Lord Yama were to come down now, they would not be able to kill me. (27) [1]

The above lines show the will power and determination of the hero of this novel. One can feel his height of joy and pride. He is very proud and happy to see ten piglets lying with the sow. He sings in ecstasy and feels he has never experienced such a joy before. He strongly feels that it is only this joy makes him to survive and says, "That's why I have survived. Otherwise after being mauled so severely by the sow, after losing so much blood, wouldn't I have died of shock?" (29) [1]

The old man sits on the top of the tree and admires the piglets by comparing it with the moon. When the moon is hidden behind the clouds, he thinks, "You don't have to come out now. Here are ten moons in the tindra bush! Who cares if you come out or don't", in fact he even calls the piglets to be more beautiful than the moon. When the moon 
is seen through the clouds, he further thinks, "Come on... come and see. In the tindra bush there are ten moons like you, in fact more beautiful" (29) [1]. In his joyful mood he never fails to thank the babbler which directed him to find his sow. He says:

Ori-your mother? I forgot you altogether. If it hadn't been for your good deed in showing me the way, I would not have seen the sow. I'd have wandered in the jungle all night. I won't forget your help in this life. When you need my help, I'll return yours tow-fold. (29) [1]

His heart is filled with gratitude, but this does not last long. When he understands that the babbler's cry is not only an invitation to him but also to the jackals and other animals, he gets irritated. Here, Reddy portrays the typical human mind which changes according to the situations and needs.

From the top of the tree, he finds a jackal meekly heading towards the shrub. The old man gets ready to attack the enemy without disturbing his sleeping sow and piglets. Before he could react, the sow suddenly leaps out of the bush like a lightning and tosses the jackal on the ground. She fights like a warrior and kills the creature. The old man from the tree admires the bravery of the sow.

The next ordeal for the old man is sitting on the tree, but he has no option. He has to stay on the tree for two reasons Firstly, to guard the sow and the new born and secondly, the sow will not let him near her. However, he motivates himself and keeps his spirit high with his sensible question which stands as a great message for the readers. He says:

But what else is life without hardship? What can a man achieve in the world without labour and without pain? It is easy to drink a bellyful of toddy and roll beneath date palms. It is easy to eat up to the nose and sleep in the corner of a loft. It is easy to leave the sow and the piglets to the wild beasts and go back to my shack. Is there any difference between those who don't recognize their responsibities and the boulders in the valley? (38) [1]

The old man feels ashamed of himself for being tired and sleepy before he fulfils his desire. His each and every word makes the readers to realize their responsibilities to reach their goal without having any set back.

There is again a threat for the sow and the piglets. Four jackals try to attack from four directions - east, west, north, and south. Sensing the danger, sow bounces on the jackal that approached her and the old man aims his spear on the other. By the time, the other two jackals run away but by picking up a piglet each. The old man is startled at this sight and cries out as:

As soon as he saw the jackals making off with the piglets the old man cried out in pain like a pregnant woman hit by a rice - pounder on the belly. He knelt on the branch as if the arrows of a hunter had struck him in the knees. His whole body began to quiver with pain as if hurt by poisonous thorns. Anguish gripped him like frost on a sunless morning. (41) [1]

When the picture of the piglets dangling from the mouth of the running jackals flashes before him, the corner of his eyes fills up. He is now worried about the fate of the piglets in the bush. As he feared, a pack of jackals starts charging toward the bush. The old man is perplexed because if it is one or two he can manage but when it is in tens, twenties or more then he cannot escape his defeat. The only weapon what he has is spear but with that he cannot save his sow and piglets. Suddenly an idea flashes in his mind but the very next minute his body starts to tremble. Now his aim is to save the piglets which will be his future and to save the piglets he has to kill his dearest sow only then he can come down from the tree and threaten the jackals to fly or he has to lose both sow and the piglets. He reacts very fastly. He kills her and like a swift, he jumps from the tree and roars at the jackals with terrifying face. They make off in different directions like cowards. The old man glances at his sow that he has reared, and kills her with his own hands. However, he consoles himself that he is helpless. With much of love and concern he tries to carry the sow. Since it is too heavy for him, he decides to leave it in the jungle. Here the author sounds very philosophical, he says, "No man is successful in everything he attempts. Life is a balance of conquests and defeats. Like the tear that reduce the burden of sorrow, the consciousness of the balance gives comfort in defeat" (55) [1]. These words relieve heaviness of the readers.

He leaves the carcass of the sow in the jungle and carries the piglets in the basket. His mind is occupied about the safety of the piglets; meantime, the entire night's struggle makes him weaker and weaker. His legs stop near the pool where he wants to rest and recover his energy. He drinks handfuls of water and quenches his thirst and lies down for a while as he is exhausted physically and mentally. His eyes close and he slips into his past. The morning light gently touches him. He wakes up but to his shock he finds four vultures sitting on the rim of the basket with the blood soaked beaks. Seeing this, he rushes to the basket and finds only eight lumps of flesh instead of eight piglets. He collapses totally. His deep sorrow is expressed as:

He stood erect. There were tears in his eyes. As he batted his eyelids, the tears slipped onto his cheeks and disappeared into his wrinkles. The jungle looked hazy to him through the film of tears. He wiped the tears with the back of his hand. Four vultures sat on a branch close by, rubbing

HuSS: International Journal of Research in Humanities and Social Sciences 
their blood soaked beaks against the branches. He felt like smashing their hearts with his spear. (61) [1]

In a dejected tone, he further expresses his physical and mental weakness as, "But now I am not even fit to hurl a spear. I ought to use a spear for support" (61) [1]. The man who fought like a warrior in order to save his sow and piglets suddenly becomes useless when he is defeated. Though a wave of self pity engulfs him, he does not allow it to overpower him for long. He tries to control his thoughts by saying:

But I must put an end to these thoughts and rest my exhausted mind. There are many things I have to do later because this is not the last day of my life. I have suffered the greatest misfortunes today and endured countless blows of ill luck. Even then it is not the last day of my life. (62) [1]
The old man is very optimistic. Though he has received countless blows, he understands that life does not end with this. One who endures pain and struggle and one who accepts defeat will be the conqueror, so the old man. His determination and unconquerable will make the readers to salute the protagonist. Neither his age nor the time of his search for the sow and her litter is a block for him. He stands as an epitome of self-confidence and positivism. His grit and tenacity at his age to attain his goal is the indefatigable human spirit which one has to celebrate.

\section{Works Cited}

1. Reddy K. He Conquered the Jungle, Chennai: Macmillan India Limited, 1998. Print. 